\title{
A Comparative Study of the Past Tense Aspects in Russian and Italian
}

\author{
Stefano M. Capilupi ${ }^{1}$, Marina N. Kulikova ${ }^{2}$, Andrey A. Shumkov ${ }^{3 凶}$ \\ ${ }^{1}$ Sapienza - University of Rome, Roma, Italy \\ ${ }_{2}^{2}$ Saint Petersburg State University, St Petersburg, Russia \\ ${ }^{3}$ Saint Petersburg Electrotechnical University, St Petersburg, Russia \\ $\otimes_{\text {noizen@mail.ru }}$
}

\begin{abstract}
Introduction. The problem of aspect categorisation in Italian, as well as in other Romance languages, is studied not so profoundly compared to what has been done in Russian linguistics. The Indo-European Presence - Aorist - Perfect in their aspectual meaning, which are the most independent forms, have turned to build the tense system both in Italian and Russian. The brightest aspectual meanings are expressed in the forms of the Past. The different perception of 'completeness' and 'incompleteness' aspects in these forms by the speakers of Italian and Russian is probably connected with the peculiarities of the tense formation on the deep level of the language system. So, additional grammar comments are needed.
\end{abstract}

Methodology and sources. The main language unit is believed to be the semifinitive. Thereby we can facilitate the application of formal logical modelling to the description and explanation of syntactic phenomena. The material of the investigation is the surface structure of a predicate, which is formed, on the deep level, by a verbal semifinitive and a time specifier.

Results and discussion. A scheme has been elaborated, demonstrating, how a verbal semifinitive becomes polarised by a time specifier. The whole range of aspectual variants, which may occur in a predicate due to the interaction of its constituents through their charges, has been shown. It is reasoned about a charge on participle II. The notion of polarisation is added to the notions of Indefinite or Perfect aspects to represent traditional grammar tenses more exact.

This investigation allows to establish a correspondence of Italian and Russian tenses to different charge states of a semifinitive, touched by a specifier. It is rather admittable that the difference between incomplete and complete aspects in Russian is expressed by participles II, which are in complex semifinitives, and in Italian - by simple semifinitives.

Conclusion. A comparative analysis of the verbal aspect category in Indo-European tenses, including the past ones, can be carried out, to our mind, both by stemming from the polarisation peculiarities of verbal semifinitives, and through investigation of literature translations, where correspondence is established on the level of language examples. In this case the genetic identity of Indo-European constructions has a chance to be represented as evidently as possible.

Key words: aspect, tense, Italian, Russian, comparative studies, binomiality idea, semifinitive.

For citation: Capilupi S. M., Kulikova M. N., Shumkov A. A. A Comparative Study of the Past Tense Aspects in Russian and Italian // DISCOURSE. 2019, vol. 5, no. 5, pp. 123-135. DOI: 10.32603/2412-8562-2019-5-5-123-135

Conflict of interest. No conflicts of interest related to this publication were reported. 


\title{
Сравнительный анализ аспектуальности в конструкциях прошедшего времени русского и итальянского языков
}

\author{
Kanилупи С. М. ${ }^{1}$, Куликова M. H. ${ }^{2}$, Шумков А. A. ${ }^{3 凶}$ \\ ${ }^{1}$ Сапиенца - Римский университет, Рим, Италия \\ ${ }^{2}$ Санкт-Петербургский государственный университет, Санкт-Петербург, Россия \\ ${ }^{3}$ Санкт-Петербургский государственный электротехнический университет «ЛЭти» \\ им. В. И. Ульянова (Ленина), Санкт-Петербург, Россия

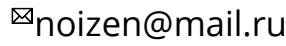

Введение. Проблема актуализации категории вида в итальянском языке, как и в других языках романской группы, изучена не так широко, как в российской лингвистике. Базой для формирования видовременной системы как итальянского, так и русского языков явились индоевропейские аспектуальные основы презенса - аориста - перфекта, представляющие собой наиболее самостоятельные формы. Особо ярко видовые значения выражаются в формах прошедшего времени. Различное восприятие оттенков совершенности-несовершенности в этих формах итальяно- и русскоязычными связано, вероятно, с особенностями построения видовременных конструкций на глубинном уровне языковой системы и требует дополнительных грамматических комментариев.

Методология и источники. Основной единицей языка избирается семифинитив, что облегчает применение метода формально-логического моделирования к описанию и объяснению синтаксических явлений. Материалом исследования являются поверхностная структура сказуемого, образованного, на глубинном уровне, глагольным семифинитивом и временным уточнителем.

Результаты и обсуждение. Процесс поляризации глагольного семифинитива временным уточнителем представлен отдельной схемой. Продемонстрирована вся гамма видовых оттенков, которые могут возникнуть в сказуемом вследствие зарядового взаимодействия его составных частей. Высказано предположение о заряде причастия II. Понятия неопределенного или перфетивного вида, используемые в традиционной грамматике для обозначения видо-временных конструкций, дополняются понятием поляризации. Проведенное исследование позволяет установить соответствие итальянских и русских видо-временных конструкций различным зарядовым состояниям семифинитива, захваченного уточнителем. Вполне допустимо, что выражение разницы между несовершенным и совершенным видами в русском языке берут на себя причастия II, входящие в состав сложных семифинитивов, а в итальянском - простые семифинитивы. Заключение. Сравнительный анализ категории глагольного вида форм времени в индоевропейских языках, в том числе форм прошедшего, возможно проводить, с нашей точки зрения, как с учетом поляризационных особенностей глагольных семифинитивов, так и посредством исследования переводных литературных источников, где сопоставление проводится на уровне языковых примеров. В этом случае генетическая тождественность индоевропейских конструкций имеет шанс на ее очевидное представление.

Ключевые слова: вид, грамматическое время, итальянский язык, русский язык, сравнительный анализ, идея двухчастности, семифинитив.

Аля цитирования: Капилупи С. М., Куликова М. Н., Шумков А. А. Сравнительный анализ аспектуальности в конструкциях прошедшего времени русского и итальянского языков // ДИСКУРС. 2019. T. 5, № 5. C. 123-135. DOI: 10.32603/2412-8562-2019-5-5-123-135

Конфликт интересов. О конфликте интересов, связанном с данной публикацией, не сообщалось. 
Introduction. The issue of aspect actualisation in Italian, as well as in other Romance languages, has not been studied as extensively as in Russian linguistics. The grammatical aspect in different languages is expressed in various ways. In the Romance languages, a separate category of the aspect is absent as such as verbal aspects are expressed implicitly or are primarily included in the semantics of the verb. The implicit form of aspect actualisation is of special interest for studying and comparing language systems in which the category of aspect exists as such. In such systems, for example, in the system of Slavic languages, the nature of the temporal meaning is expressed by morphological means. The semantics of the verb, however, remains very important.

The verb aspect is a grammatical category that shows the nature of temporal meaning and expresses the relationship of the action to its internal limit [1]. This category is found in almost all languages of the world; Russian and Italian are no exception. However, languages that differ in structure are characterised by different ways of actualising aspectual meanings. It is clear that the Pre-Slavic language and Latin have a common ancestor - the Proto-Indo-European language. Since the branch of the East Slavic languages, which includes the Russian language as well, was estranged from the Proto-Indo-European language more than others, it is more logical to trace the formation of the aspect from Old Russian. When studying the stages of the formation of modern verb forms that convey aspectual meanings in the Italian language, it will be reasonable to turn to the IndoEuropean language (stages of its development, and its peculiarities), and then to Latin.

The tense-aspect system of both Italian and Russian was formed on the basis of the IndoEuropean aspect of Present - Aorist - Perfect, which are essentially the most independent forms.

The contrast between the perfective and imperfective aspects is found quite clearly in Old Russian manuscripts. Moreover, this contrast had a formal expression by some means or other. The category of aspect has undergone the most serious and profound changes [2]. Well-structured aspect categories that determine the temporal meaning caused the formation of the category of grammatical tense. The Old Russian verb possessed two simple forms of the past tense (Aorist and Imperfect) and two complex ones (Perfect and Plusquamperfect). These forms can be described more accurately as tense-aspect ones, as they indicated the action relative to the moment of speech, completed (incompleted) actions, single (multiple) actions, their duration and resultativeness.

Aorist denoted an action that was immediate, single or lasting for some time and completed in the past [3]. A distinctive feature of Aorist is that it 'closes in itself', i. e. it shows a state, an action at a certain moment in the past. The action as such, expressed by Aorist, happened, and when it happened and how long it took is not so important. According to A. A. Shakhmatov, Aorist survived in constructions with a special use of the imperative mood to express the sudden and noncontinuous action that happened in the past: 'take and run', 'take and fall' [3, 4]. Imperfect was an indicator of continuous or repeated action. It should be noted that perfective verbs with prefixes reveal a connection with Aorist, and the same imperfective verbs with prefixes reveal that with Imperfect. Plusquamperfect is the pluperfect tense used to indicate an action in the past that preceded another action in the past. Perfect is the result of a past action

The split of the common Indo-European language led to the fact that the systems of tense in different languages developed individually. As a result of the development of differences in tense forms, it became also possible to show the relationship of actions in their duration. Additionally, with the development of tense forms, the former aspect differences disappear almost completely in some languages, while in the Slavic languages appears a new aspect opposition 'Perfect-Imperfect'. We can also say that the grammatical aspect was formed as a 'resource mechanism' that links the lexical 
semantics of the verb with its temporal potential [5]. This grammatical category substituted for many past tense forms as a result of the appearance of prefix word formation.

The means of aspect expressing in Old Russian were alternating vowels. Long vowels marked any duration of an action, while short vowels were usually used in stems expressing a short or single action [6]. Verbs were divided into three groups: terminative, non-terminative, and neutral. The core of the group of terminative verbs were resultative, differentiating the process of action aimed at the result and achieving the result. This used to be expressed in the same verb [3]. The distinction was made according to the pre-Slavic model, where a definite action was opposed to that of indefinite through an alternating vowel (е. g., соберати-собирати). Thus, paired verbs appeared. New verbs received the meaning of imperfectives.

One of the most important ways of word formation is prefixation. It was an integral part of the formation of the aspect category, since the prefix affects not only the belonging to a particular aspect, but also often adds some lexical meaning.

Additionally, suffixes, e. g., $и в a,-b l в a$, played an important role, which make it possible to convert easily prefixed verbs into imperfective verbs. Consequently, such verbs form pairs, and, therefore, 'the specific meanings of both its members become clearer, that is, the meaning of the perfect form is finally formed' [3].

The category of aspect plays one of the most important roles in the formation and transformations of Old Slavic, then Old Russian. It has therefore a strong influence on the modern Russian language.

The formation of the category of aspect also influenced the formation of future tense forms. The final stage in the formation of the tense-aspect system was the formation of the future simple tense, since simple forms are formed only from perfective verb forms. The future complex tense was formed with the help of the perfect participle and the auxiliary verb ' 6 blmb'. However, the final establishment of the analytical form was expressed in a combination of the present simple form of the verb 'бolmb' and an imperfective infinitive. Here we are faced with the fact that the perfective verb 'бbımb' cannot create a pair with the verb expressing the completed action.

For a clear understanding of the category of aspect in the Italian language, we consider the changes that took place in the Proto-Indo-European language, based on the periods presented by W. Meid [7]:

- the Early Indo-European period (6000-4500 BC);

- the Middle Indo-European period (4500-3500 BC);

- the Late Indo-European period (3500-2500 BC).

There are also other periodisation models proposed, for example, by T. V. Gamkrelidze and V. V. Ivanov, M. West, and N. Andreev. However, W. Meid's model seems to us the most appropriate one for tracking the formation of tense-aspect system.

In the early Indo-European period, the verb system carried a double opposition, where the common system of Present-Aorist, which denoted an action was opposed to the perfect system, which denoted a state [8]. Some linguists (T. Elizarenkova, A. N. Savchenko) believe that presence and aorist already existed before Perfect (the identity of their endings makes it possible to draw such a conclusion, since Perfect is characterised by other endings). The similarity of the roots also makes it possible to assume that they had a single form, subsequently divided into two [4, 3].

The 'Present-Aorist' form, presumably a single one, refers to the Early Indo-European period, which ends with the formation of the languages of the Anatolian branch (languages of the peoples of Asia Minor and Northern Syria: the Hittites, Luwians and Palaic peoples). In the Middle Indo-European period, languages got separated, since the roots of the presence denoted a continuous incompleted action, and 
the roots of Aorist referred to a non-continuous and completed action. Thus, the assumed separation of Aorist from Present could occur due to the acquisition of a new meaning, which refers to completenessincompleteness. Consequently, there appeared a need to separate these two forms through affixation or changes in the roots. At first, the difference between the Aorist form and that of Present was insignificant, but gradually they became more and more different from each other.

In relation to the third stage of the development of the Indo-European verb, it is necessary to note the formation of primary endings to express the present tense, as well as the formation of the category of tense in general. Along with the formation of the endings of the present tense, another tense category is formed in it - Imperfect. Imperfect differed from Aorist in that it had a present verb base. A marker that differentiated it from Present was a special inflection.

Over time, already in Latin, the aspect began to be expressed in the opposition 'InfectumPerfectum'. Infectum and Perfectum indicate the completeness or incompleteness of the action. These systems include certain verb tenses: Present, Futurum and Imperfectum are classified as Infectum, the rest are as Perfectum. It can be said that Perfectum is a system inherited from the Indo-European language in which Perfectum was defined as a state achieved as a result of past actions [9]. It always had differences in the root base and features of inflection.

The aspect in Latin with its distinctive features of the Perfectum and Infectum bases was lost. Consequently, there are no Latin aspectual meanings of Perfect, Futurum and Plusquamperfect in Italian. Aspectual meanings are most vividly expressed in past tense forms. Imperfect of the indicative mood is expressed through the tense form Imperfetto, where a verb form is formed with the suffix $-a v$ - for the verbs of the $1^{\text {st }}$ conjugation; $-e v$ - is used for the verbs of the $2^{\text {nd }}$ conjugation; and $-i v$ - for the verbs of the $3^{\text {rd }}$ conjugation. A simple perfect tense (Passato remoto) is formed by changing the endings that come from Latin: $-i$; -ste; - $u$; -mos; -stes; -ram. However, in the modern language, for the most part, Passato Prossimo is used to convey the perfect meaning. It is a complex (compound) perfect tense where the verb base often remains unchanged.

Differences in understanding the imperfect past tense in Italian and Russian are to be examined more carefully. In modern Italian, the past tense can be expressed by five forms: Passato Prossimo, Imperfetto, Trapassato Prossimo, Passato Remoto, and Trapassato Remoto. In modern Russian, in fact, only one form is found, but it is formed from verbs of two different types perfective and imperfective (completed and incompleted).

I. M. Teterukova, in her dissertation 'Grammar Transformations of Text in Translation: A Case Study of the Italian and Russian languages', says that 'Italian past tense Imperfetto $<\ldots>$ is translated into Russian using imperfective verbs, but reverse translation is not always possible, that is, Russian imperfective verbs can also be translated with the help of Passato Prossimo and Passato Remoto'. She also classifies the construction of 'stare+gerundio' as the expression of Imperfect, since, when translated into Russian, this construction requires an imperfective verb [10].

However, Italian grammarians (Dardano; Grandi) classify the periphrasis construction 'stare+gerundio' as another aspect of the verb, which they call 'Progressivo' $[11,12]$.

These contradictions emerge mainly because of the different definitions of the concept of the 'imperfective'. In Russian grammar, the term 'imperfective' is broader than in Italian, since there are verb pairs in Russian - 'aspectual verb pairs'. In Italian grammar, where the category of aspect is not generally expressed in the verb, but is conveyed through the verb form. In particular, the imperfective exists only in the form of the past continuous tense Imperfetto. In Russian, the 
imperfective shows the duration of the process, where the emphasis is on the duration of the action, that is, on its process. It often turns out that the Russian imperfective verb is translated into Italian through Passato Prossimo or Passato Remoto, i. e. the tenses that express the perfective.

In Italian, the imperfective of Imperfetto is used to express the state of an object or subject of a statement; in Russian, an imperfective verb expresses mainly a continuous (and continuing) process.

Therefore, when describing how the imperfective is expressed in Italian, it is necessary to correctly highlight key points. According to the grammar of the Russian language, we can deal with an imperfective verb, but it cannot always be translated so that the aspectual meaning is preserved, because the imperfective in Italian exists only in the specific past tense verb form, and is not found, for example, in the present tense.

It appears that for a clearer understanding of the situation in which a verb expressing a certain action in the past is an imperfective verb, it is necessary to introduce such terms as 'incompiuto' (incompleteness) and 'indefinito' (temporary indefiniteness). It can be said that the tense form which contains the imperfective meaning in Italian grammar is responsible for a certain state of the object or subject of the utterance in the past. The form expressing the result, even if not explicitly uttered in the statement, refers to the perfective.

Russian grammar uses the term 'perfective', which should not be considered the equivalent of the Italian term 'Perfettivo' ('Passato Remoto'), since this form in modern language emphasises the action out-of-dateness. 'Compiuto' ('Passato Prossimo') is mainly used in texts related to historical events. It expresses an action that is completed, in which emphasis is placed on the result, therefore, to call 'Compiuto' the perfective, based on the terminology of Russian linguistics, is not entirely correct, it is rather the 'completed aspect'.

The 'perfective' and 'completed' aspects have obviously different aspectual meanings. Speaking of the completed aspect, we are talking about the verb form Passato Prossimo, through which the meaning of the integrity of an action, an action with time limits, is expressed. The Italian perfective is expressed by Passato Remoto. Here we again deal with the temporal limits of the action, its completeness and a kind of somewhat passé.

A crucial role in actualisation of the Italian category of aspect is played by periphrasis constructions. G. Abramenko examines them in detail in her book 'Italian. Translation difficulties'. She says that 'they are a combination of an auxiliary verb, that varies in persons, numbers, tenses and moods, with the non-personal verb form' [13]. Periphrases are constructed with an infinitive that indicates that the action is completed and it is perfect. They can also express a modal or causative meaning, or with gerund in the present tense they usually convey an action in its duration, and in the past they express an action that has an internal limit.

It can therefore be concluded that the imperfective in Italian and Russian grammar is not identical and differ in semantic meaning. The 'imperfective' from the point of view of Russian grammar may not coincide with the 'imperfective' in Italian grammar and can be expressed not only with the help of Imperfetto. It can also be expressed with the help of various verb constructions, while the 'imperfective' in Italian grammar implies the only possible way of expression through Imperfetto. The term 'perfective' in Russian grammar implies two terms in Italian grammar: 'completed' ('compiuto'), which is most often expressed through Passato Prossimo and 'perfect' ('perfettivo') through Passato Remoto.

Such a different perception of the variants of perfection-imperfection in the past tense in Italian and Russian is likely to be associated with the peculiarities of constructing tense-aspect 
structures at the deep level of the language system. It is not unlikely that at this level the structures under discussion are similar. However, these structures differ at the surface level. In fact, the (simple) past tense in modern Russian goes back to the present perfect tense, formed on the auxiliary imperfective verb 'являться'. The participles that make up this perfective can be formed from both perfective and imperfective verbs. As will be shown below, they can quite productively correspond to all five past tenses of Italian. It should be also noted that the main reason for this pattern is the elimination of the auxiliary verb 'являться', because without it the present perfect tense can be taken for the past perfect one.

Methodology and sources. In papers that have been written at St. Petersburg Electrotechnical University since 1993, the issue of the basic unit of the language has been repeatedly raised. And at some point it was made a very reasonable assumption about what kind of linguistic phenomenon might represent it $[14,15]$.

The main unit of language is, in our understanding, the verbal semifinitive, which can be found in the compound predicates like He could say that or He does not say that (see is here a semifinitive, which is on the half-way to its finite verbal form).

It is interesting to note, that, in our assumption, the verbal semifinitive can give a birth to the substantive semifinitive, which can be found in the compound subjects like It is important to say that or There is a saying about that (to say that and a saying about that are here semifinitives, which are on the half-way to their finite substantive forms). This is new, because there has never been a notion of a finite substantial form, but we think formally - if a finite verbal form exists (a predicate), why not allow the existence of a finite substantive form (a subject)?

This article however concerns verbal phenomena, that is why we should profoundly consider the verbal semifinitive. The method we choose is formal logical modeling, but with the use of physical categories, whuch is totally new for linguistics.

We presumed that energy is a clot of time. It means that the density of energy is higher than the density of time. Let us then say, that energy is charged positively, and time - negatively. Being a wave, a verbal semifinitive is fluctuating at a certain frequency and we get a certain discrepancy between membrane and cavity. The resulting charge of verbal semifinitive will be then positive or negative. Taking into account that participles have verbal nature, we may expect them to be also charged. In this case it is reasonable to keep them inside the cavities of verbal semifinitives, because the resulting charge of these semifinitives will then never be disturbed. In parallel to this (even despite having no charge) postpositional augments are also distributed into the cavities.

The verbal semifinitives without participles will be just called as simple verbal semifinitives (e. g., the verbal semifinitives take and take off are simple).

The verbal semifinitives with participles will be called as complex verbal semifinitives (e. g., the verbal semifinitives have taken and be taken off are complex).

We have stipulated that substantive semifinitives (not fluctuating) are charged neutrally and verbal semifinitives - positively or negatively. In modern English the verbal semifinitives, including have as uninflected word, are negatively charged, and the other verbal semifinitives are charged positively. The reason for this seems to be the following. In the have-semifinitives (which we will call as semifinitives II) we always meet participle(s) II, distributed into the cavity. It means that the meaning is brighter in the cavity, which is negatively charged. In other semifinitives (which we will call as semifinitives I) the meaning is brighter in the membrane, which is positively 
charged. Tracking the meaning we endure the verbal semifinitive charge. The charge of substantive semifinitive is indifferent to meaning tracking.

When touched by a negative proto-specifier or specifier a neutral substantive semifinitive undergoes no polarisation. A positive or negative verbal semifinitive, touched by a negative protospecifier or specifier, undergoes a polarisation, dependent on: from where the proto-specifier or specifier approaches the verbal semifinitive (from below or from above); how this semifinitive is positioned (as seen from the scheme, the arrays of strong and super-weak semifinitives are positioned inversely to each other); which charge this semifinitive has (positive or negative); how this semifinitive is touched (from down- or upstairs). As we see, the above-mentioned structures are subject and predicate. The materials which are of the most interest in this paper are predicate structures in their thejretical representation.

Results and discussion. We have taken into consideration a verbal semifinitive, touched by a time specifier. The process of polarisation in the predicate being formed runs as follows.

Present-tense specifier (negative), approaching from above, touches strong semifinitive I (positive) from upstairs. In the process of approaching the specifier attracts the semifinitive but the semifinitive membrane cannot be (clearly) touched because of its size and such a predicate is impossible (1.1).

Present-tense specifier (negative), approaching from above, touches super-weak semifinitive I (positive) from upstairs. In the process of approaching the specifier attracts the semifinitive and after clearly having touched the semifinitive cavity causes the futurity aspect to emerge: Girls will play dolls. (1.2).

Present-tense specifier (negative), approaching from above, touches strong semifinitive I (positive) from downstairs. In the process of approaching the specifier attracts the semifinitive and after unclearly having touched semifinitive cavity causes the indefinite aspect to emerge: Girls play dolls (1.3).

Present-tense specifier (negative), approaching from above, touches super-weak semifinitive I (positive) from downstairs. In the process of approaching the specifier attracts the semifinitive and after unclearly having touched the semifinitive membrane causes the indefinite aspect to emerge: Girls play dolls (1.4).

Present-tense specifier (negative), approaching from above, touches strong semifinitive II (negative) from upstairs. In the process of approaching the specifier repels the semifinitive but the semifinitive membrane cannot be (unclearly) touched because of its size and such a predicate is impossible (2.1).

Present-tense specifier (negative), approaching from above, touches super-weak semifinitive II (negative) from upstairs. In the process of approaching the specifier repels the semifinitive and after unclearly having touched the semifinitive cavity causes the uncertain futurity aspect to emerge, which can be made certain by indicating the time: Girls will have played dolls by 5 o'clock (2.2).

Present-tense specifier (negative), approaching from above, touches strong semifinitive II (negative) from downstairs. In the process of approaching the specifier repels the semifinitive and after clearly having touched the semifinitive cavity, causes the incomplete (time-log) aspect to emerge: Girls have played dolls (for two hours) (2.3).

Present-tense specifier (negative), approaching from above, touches super-weak semifinitive II (negative) from downstairs. In the process of approaching the specifier repels the semifinitive and after clearly having touched the semifinitive membrane, causes the complete (perfect) aspect to emerge: Girls have (just) played dolls (2.4). 
Past-tense specifier (negative), approaching from below, touches strong semifinitive I (positive) from upstairs. In the process of approaching the specifier attracts the semifinitive but the semifinitive membrane cannot be (unclearly) touched because of its size and such a predicate is impossible. (3.1).

Past-tense specifier (negative), approaching from below, touches super-weak semifinitive I (positive) from upstairs. In the process of approaching the specifier attracts the semifinitive and after unclearly having touched the semifinitive cavity causes the subjunctive futurity aspect to emerge: Girls would play dolls (if they had them) (3.2).

Past-tense specifier (negative), approaching from below, touches strong semifinitive I (positive) from downstairs. In the process of approaching the specifier attracts the semifinitive and after clearly having touched the semifinitive cavity, causes the incomplete (time-log) aspect to emerge: Girls played dolls (for two hours) (3.3).

Past-tense specifier (negative), approaching from below, touches a super-weak semifinitive I (positive) from downstairs. In the process of approaching the specifier attracts the semifinitive and after clearly having touched the semifinitive membrane, causes the complete (perfect) aspect to emerge: Girls (already) played dolls (3.4).

Past-tense specifier (negative), approaching from below, touches strong semifinitive II (negative) from upstairs. In the process of approaching the specifier attracts the semifinitive but the semifinitive membrane cannot be (clearly) touched because of its size and such a predicate is impossible. (4.1).

Present-tense specifier (negative), approaching from below, touches super-weak semifinitive II (negative) from upstairs. In the process of approaching the specifier attracts the semifinitive and after clearly having touched the semifinitive cavity causes the futurity aspect to emerge: Girls would have played dolls (4.2).

Past-tense specifier (negative), approaching from below, touches strong semifinitive II (negative) from downstairs. In the process of approaching the specifier attracts the semifinitive and after unclearly having touched semifinitive cavity causes the indefinite aspect to emerge: Girls had played dolls (4.3).

Past-tense specifier (negative), approaching from below, touches super-weak semifinitive II (negative) from downstairs. In the process of approaching the specifier attracts the semifinitive and after unclearly having touched the semifinitive membrane causes the indefinite aspect to emerge: Girls had played dolls (4.4).

The polarisation peculiarities can roughly be generalised in the following scheme (fig.): $\mathrm{min}-$ small cavity, the futurity aspect; max - large cavity, the incomplete (time-log) aspect; perf - small membrane, the complete (perfect) aspect; imp - large membrane, the imperfect aspect, not existing.

The polarisation of verbal semifinitives corresponds to indefinite and perfect aspects in the sense of traditional grammar.

In Russian, as we assume, the imperfective indicative past tense corresponds to construction 2.3 and, possibly, 4.3 ; the perfective indicative past tense - construction 2.4 and, possibly, 4.4 (we can also note the correspondence of construction 4.2 to the subjunctive past tense of the imperfective or perfective - Я делал бы or Я сделал бы).

In Italian, we assume the following correspondences: Passato Prossimo - 2.3 and 2.4; Imperfetto - 3.3; Trapassato Prossimo - 4.3 and 4.4; Passato Remoto - 3.4; Trapassato Remoto 4.3 and 4.4 . 


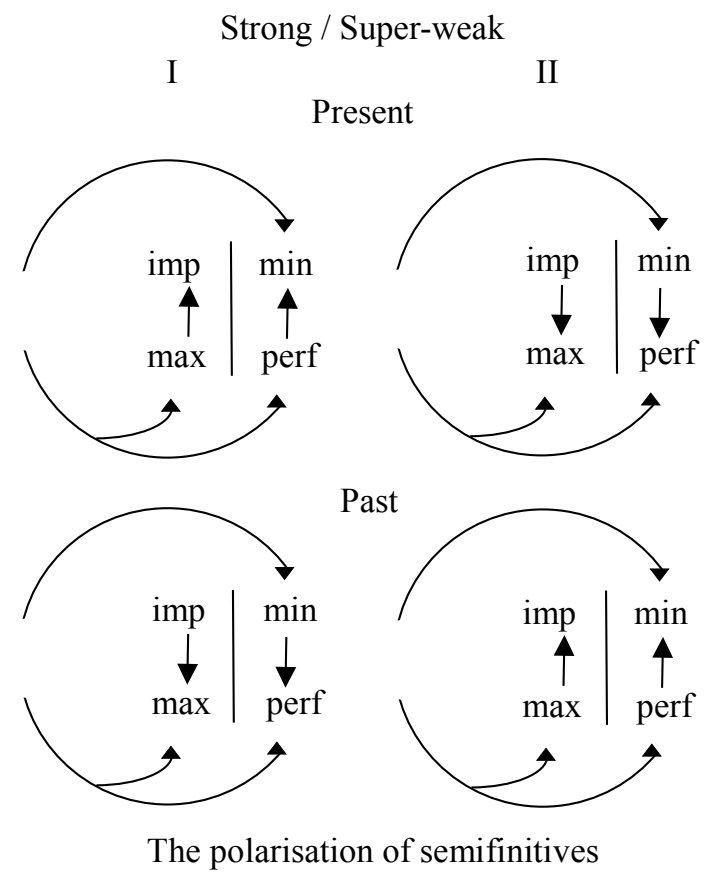

Thus, the difference between the imperfective and perfective in Russian is expressed by the participles II, which are part of complex semifinitives. In Italian it is expressed by simple semifinitives. This is quite acceptable, since participles II, in their aspectual difference are parallel to simple semifinitives.

In Russian, a complex semifinitive, generally speaking, can express an aspect in four ways, since the auxiliary verb and the participle II are both perfect and imperfect:

- являться делал (imperf.+imperf.);

- являться сделал (imperf.+perf.);

- быть делал (perf.+imperf.);

- быть сделал (perf.+perf.).

The difference between the verbs 'быть' and 'являться' is determined by the aspectual opposition 'completeness' - 'incompleteness', therefore the last construction in modern Russian is used only in the subjunctive mood.

In Italian, in past tenses, Trapassato Prossimo and Trapassato Remoto, the auxiliary verb in the form of Imperfetto expresses the imperfective, and in the form of Passato Remoto it denotes the perfective. However, the aspectual neutrality of participle II does not lead to significant aspectual differences. It should be added that in English Italian tenses Trapassato Prossimo and Trapassato Remoto are translated by the same form - Past Perfect. At the same time, in modern Italian, Trapassato Prossimo is more common.

Conclusion. A comparative study of the category of the aspect of tense verb forms in IndoEuropean languages can be carried out, from our point of view, in two directions. The first direction takes into account the polarisation features of verb semifinitives and adheres to the above scheme, with which various tense-aspect constructions can be compared. The second direction refers to the study of translated literary sources, where the comparison is carried out at the level of language examples. One can raise the issue whether the third direction that studies living speech might exist. However, oral speech, in comparison with written one, does not use the entire range of tense-aspect structures. There is a tendency to reduce their number. 
The category of past tense verb forms in Russian and Italian can be considered according to the first two directions, which has been done in this paper. Literary examples, from our point of view, should be compared not only with each other, but also with the scheme of semifinitive polarisations. In this case, the genetic identity of Indo-European constructions has a chance of its obvious representation. The actual identity of the deep tense-aspect structures makes it possible for us to consider specific surface realisations of tense-aspect structures in Russian and Italian in a more visual representation.

\section{REFERENCES}

1. Rozental, D.E. and Telenkova, M.A. (1976), Slovar-spravochnik lingvisticheskikh terminov [The reference dictionary of linguistic terms], Prosveshchenie, Moscow, USSR.

2. Kuznetsov, P.S. (2002), Ocherki po morfologii praslavyanskogo yazika [Essays on morphology of the Proto-slavic language], 2nd ed., Editorial URSS, Moscow, Russia.

3. Ivanov, V.V. (1990), Istoricheskaya grammatika russkogo yazika [The historical grammar of Russian], 3nd ed., Prosveshchenie, Moscow, USSR.

4. Borkovskiy, V.I. and Kuznetsov, P.S. (2006), Istoricheskaya grammatika russkogo yazika [The historical grammar of Russian], KomKniga, Moscow, Russia.

5. Avilova, N.S. (1976), Vid glagola i semantika glagolnogo slova [The aspect of Verb and sematyics of a verbal word], Nauka, Moscow, USSR.

6. Bogatyreva, I.I. (1997), "Comparative historical morphology of Indo-European Languages" Sravnitelno-istoricheskaya morfologiya indoevropeyskikh yazikov [Comparative historical Indo-European linguistics], Dialogue-MGU, Moscow, USSR.

7. Savchenko, A.N. (1960), Problema proiskhozhdeniya lichnykh okonchaniy glagola $v$ indoevropeyskom yazike [The problem of the origin of personal verbal endings in the Indo-European language], Rostov Univ. Publ., Rostov-na-Donu, USSR.

8. Bogatyreva, I.I. and Kazaryan, V.K. (2004), "The development of the aspect-tense system in the early Indo-European period and its further evolution", Sravnitelno-istoricheskoye I obshchee yazikoznanie [Comparative historical and general linguistics], Dobrosvet, Moscow, Russia.

9. Kurysheva, M.V. (2011), Istoriya russkogo yazika: istoricheskiy kommentariy na urokakh russkogo yazika $v$ nachalnoy shkole [The history of Russian: a historical comment for the lessons of Russian at primary school], TGPU Publ., Tomsk, Russia.

10. Teterukova, I.M. (2009), "Grammatical transformations in a text under translation (on the material of Italian and Russian)", Cand. Sci. (Philology) Thesis, Moscow State Univ., Moscow, Russia.

11. Smirnov, P.L. (2017), "...I ne pos/usha ikh...». Sudbonosnye sovety, obrashchyonnye k knyazyam v «Povesti vremennykh let» [«...And not having listened to them...» Crucial advices, directed to dukes in «The tale of bygone years»], Russkaya rech, no. 6. pp. 56-60.

12. Umberto, E. (2013), Il nome della rosa, Bompiani, Milano, ITA.

13. Abramenko, G.A. (2011), Italyansky yazik. Trudnosti perevoda [Italian language. Difficulties of translation], Astrel, Moscow, Russia.

14. Ulianitckaia, L.A. and Shumkov, A.A. (2018), "The physical base of communication on natural language", 2018 IEEE Communication Strategies in Digital Society Seminar (2018 ComSDS), SPb., Russia, 11 Apr. 2018, pp. 72-75.

15. Shumkov, A. (2017), "Modeling Natural Language on Physical Concepts", $6^{\text {th }}$ Intlernational Conf. on Meaning and Knowledge Representation, SPb., Russia, 5-7 July 2017, pp. 68-69.

\section{Information about the authors.}

Stefano M. Capilupi - Can. Sci. (Philosophy) (2006), Subject Expert at the Chair of Political Philosophy of University of Rome La Sapienza, 5 Piazzale Aldo Moro, 00185 - Roma, RM, Italy. 
The author of 40 scientific publications. Area of expertise: the history of Italian language, art and philosophy, Christianity doctrines in philosophical aspects, the theory of language. ORCID: https://orcid.org/0000-0003-0063-8197. E-mail: s_capilupi@yahoo.it

Marina N. Kulikova - Can. Sci. (Philology) (2011), Senior Lecturer at the Department of English in Philology and Arts, Saint Petersburg State University, 7/9 University emb., St Petersburg 199034, Russia. The author of 15 scientific publications. Area of expertise: stylistics, translation studies, theoretical grammar. ORCID: https://orcid.org/0000-0003-2501-9894. E-mail: m.kulikova@spbu.ru

Andrey A. Shumkov - Dr. Sci. (Philology) (2009), Docent (2007), Head of the Department of Foreign Languages, Saint Petersburg Electrotechnical University, 5 Professora Popova str., St Petersburg 197376, Russia. The author of 100 scientific publications. Area of expertise: grammar of Germanic languages, the theory of language, translation studies, linguistic contacts. ORCID: https://orcid.org/0000-0001-7326-4371. E-mail: noizen@mail.ru

\section{СПИСОК ЛИТЕРАТУРЫ}

1. Розенталь Д. Э., Теленкова М. А. Словарь-справочник лингвистических терминов. М.: Просвещение, 1976.

2. Кузнецов П. С. Очерки по морфологии праславянского языка. 2-е изд., стереотип. М.: Едиториал УРСС, 2002.

3. Иванов В. В. Историческая грамматика русского языка: учеб. 3-е изд., перераб. и доп. М.: Просвещение, 1990.

4. Борковский В. И., Кузнецов П. С. Историческая грамматика русского языка. 3-е изд., стереотип. М.: КомКнига, 2006.

5. Авилова Н. С. Вид глагола и семантика глагольного слова. М.: Наука,1976.

6. Богатырева И. И. Сравнительно-историческая морфология индоевропейских языков // Сравнительно-историческое индоевропейское языкознание. М.: МГУ, 1997. С. 21-29.

7. Савченко А. Н. Проблема происхождения личных окончаний глагола в индоевропейском языке. Ростов н/Д. : Изд-во Рост. ун-та, 1960.

8. Богатырева И. И., Казарян В. К. Становление видо-временной системы в раннеиндоевропейском периоде и дальнейшее ее развитие // Сравнительно-историческое и общее языкознание. М.: Добросвет, 2004. С. 129-138.

9. Курышева М. В. История русского языка: исторический комментарий на уроках русского языка в начальной школе: учеб.-метод. пособие. Томск: Изд-во ТГПУ, 2011.

10. Тетерукова И. М. Грамматические трансформации текста при переводе (на материале итальянского и русского языков): дис. ... канд. филол. наук / МГУ. М., 2009.

11. Смирнов П. Л. «...И не послуша ихъ...». Судьбоносные советы, обращенные к князьям в «Повести временных лет» // Русская речь. 2017. № 6. С. 56-60.

12. Umberto E. II nome della rosa. Milano: Bompiani, 2013.

13. Абраменко Г. А. Итальянский язык. Трудности перевода. М.: Астрель, 2011.

14. Ulianitckaia L. A., Shumkov A. A. The physical base of communication on natural language // 2018 IEEE Communication Strategies in Digital Society Seminar (2018 ComSDS). SPb.: ETU, 2018. P. 72-75.

15. Shumkov A. Modeling Natural Language on Physical Concepts // $6^{\text {th }}$ International Conf. on Meaning and Knowledge Representation: Book of Abstracts. SPb: Expert-legal center Publ., 2017. P. 68-69.

\section{Информация об авторах.}

Капилупи Стефано Мария - кандидат философских наук (2006), внешний научный консультант кафедры политической философии Римского государственного университета «Ла Сапьенца» (Италия), Пьяццале Альдо Моро, 5, 00185 - Рим, РМ, Италия. Автор 40 
научных публикаций. Сфера научных интересов: история итальянского языка, искусства и философии, философские аспекты Христианских доктрин, теория языка. ORCID: https:/orcid.org/0000-0003-0063-8197.E-mail: s_capilupi@yahoo.it

Куликова Марина Николаевна - кандидат филологических наук (2011), старший преподаватель кафедры английского языка в сфере филологии и искусств Санкт-Петербургского государственного университета, Университетская наб., д. 7/9, Санкт-Петербург, 199034, Россия. Автор 15 научных публикаций. Сфера научных интересов: стилистика, переводоведение, теоретическая грамматика. ORCID: https://orcid.org/0000-0003-2501-9894. E-mail:m.kulikova@spbu.ru

Шумков Андрей Арнольдович - доктор филологических наук (2009), доцент (2007), заведующий кафедрой иностранных языков Санкт-Петербургского государственного электротехнического университета «ЛЭТИ» им. В. И. Ульянова (Ленина), ул. Профессора Попова, д. 5, Санкт-Петербург, 197376, Россия. Автор 100 научных публикаций. Сфера научных интересов: грамматика германских языков, теория языка, переводоведение, лингвистическая контактология. ORCID: https://orcid.org/0000-0001-7326-4371. E-mail: noizen@mail.ru 